\title{
PENGARUH KUALITAS PELAYANAN TERHADAP KEPUASAN NASABAH PADA PT. MANDIRI TUNAS FINANCE CABANG PEKANBARU
}

\author{
Teuku Reza Kurniawan \\ Sekolah Tinggi Ilmu Ekonomi Riau \\ E-mail: teukurezhakurniawan@gmail.com
}

\begin{abstract}
This research was conducted at PT. Mandiri Tunas Finance Pekanbaru Branch. The purpose of this study was to determine the Effect of Service Quality on Customer Satisfaction at PT Mandiri Tunas Finance Pekanbaru Branch. The population in this study was 2,390 customers. In this study sampling using Accidental Sampling techniques, which amounted to 96 customers. The data used are primary and secondary data with analysis using simple linear regression. The results showed $Y=$ $14.820+1.035$ and the $t$ test showed that $t$ arithmetic $>$ from t table $(18,471>1,98552)$ this meant that Quality of Service had a significant effect on Customer Satisfaction of PT. Mandiri Tunas Finance Pekanbaru Branch. The influence of Service Quality on Customer Satisfaction is $78.4 \%$ while the remaining $21.6 \%$ is influenced by other variables.
\end{abstract}

Keywords: Service Quality and Customer Satisfaction

\section{A. PENDAhuluan}

Era globalisasi persaingan bisnis menjadi semakin sangat tajam, baik dipasar domestik (nasional) maupun dipasar internasional. Perusahaan memerlukan strategi untuk menghadapi persaingan yang saat ini semakin lama semakin ketat. Terdapat berbagai tantangan dalam mencapai keberhasilan perusahaan. Untuk mengantisipasinya, perusahaan dituntut untuk dapat bekerja dengan baik dengan menggunakan berbagai macam sumber daya yang dimiliki agar dapat diterima di pasar. Salah satu yang perlu diperhatikan perusahaan dalam mencapai keberhasilan adalah kualitas pelayanan.

Pelayanan pada dasarnya adalah kegiatan yang ditawarkan oleh organisasi atau perorangan kepada konsumen, yang bersifat tidak berwujud dan tidak dapat dimiliki. Secara umum, pelayanan di Indonesia masih dinilai kurang baik dan dianggap bertele-tele sehingga masalah tersebutlah yang harus diperbaiki oleh perusahaan dan lembaga lainnya agar dapat merubah citra buruk tersebut menjadi lebih baik. Seperti yang kita ketahui, masalah adalah ketidaksesuaian suatu keadaan dengan apa yang diinginkan. Begitu juga halnya dalam dunia perbankan, perkembangan teknologi yang semakin maju membuat keunggulan suatu produk sulit untuk dipertahankan, karena pada dasarnya produk lebih mudah untuk ditiru. Untuk itulah, pelayanan yang baik dan berkualitas sangat diperlukan agar dapat memberikan pelayanan yang prima dan kualitas sesuai yang diinginkan serta diharapkan oleh para nasabahnya agar dapat membuat nasabah merasa puas.

Keberhasilan suatu perusahaan sangat dipengaruhi oleh kinerja individu karyawannya. Setiap perusahaan akan selalu berusaha untuk mendapatkan kinerja terbaik dari karyawannya, dengan harapan apa yang menjadi tujuan perusahaan akan tecapai

Perusahaan leasing memiliki peran yang cukup penting dalam pembiayaan barang-barang modal atau barang konsumtif.Jenis barang yang dibiayain pun terus meningkat. Jika sebelumnya hanya terfokus pada pembiayaan kendaraan bermotor, kini berkembang pada keperluan kantor, manufaktur, konstruksi dan pertanian. Hal ini mengindikasikan multi finance kian dikenal dan diandalkan oleh pelaku usaha nasional.

Kepuasan nasabah menjadi sangat penting bagi suatu perusahaan, yang dalam penelitian ini adalah perusahaan yang bergerak di bidang jasa perbankan, di mana pelayanan yang baik memegang peran utama dalam memberikan kepuasan kepada para nasabahnya. Dengan pelayanan ini maka akan memunculkan suatu tingkat kepuasan pada nasabah baik itu kepuasan positif 
maupun kepuasan negatif. Bagi perusahaan perbankan suatu kepuasan nasabah sangat diperlukan khususnya dalam rangka eksistensi perusahaan tersebut, sehingga nasabah tersebut akan tetap menggunakan jasa perusahaan tersebut.

\begin{tabular}{cccr}
\multicolumn{2}{c}{ Kualitas pelayanan adalah } & segala \\
sesuatu & yang memiliki nilai & dipasar \\
sasaran & (target market) & dimana
\end{tabular}
kemampuannya memberikan manfaat dan kepuasan, termasuk hal ini adalah benda, jasa, organisasi, tempat, orang dan ide. Dalam hal ini perusahaan memusatkan perhatian mereka pada usaha untuk menghasilkan pelayanan yang unggul dan terus menyempurnakan. Pelayanan yang berkualitas tinggi merupakan salah satu kunci sukses perusahaan.

Memperbaiki kualitas pelayanan ataupun jasa merupakan tantangan penting bagi perusahaan bersaing di pasar global. Perbaikan kualitas pelayanan akan mengurangi biaya dan meningkatkan keunggulan bersaing, bahkan lebih jauh lagi, kualitas pelayanan yang tinggimenciptakan keunggulan bersaing yang tahan lama.

Pada perusahaan yang bergerak dibidang jasa yang berorientasi kepada kepuasan nasabah (pelanggan), perusahaan harus senantiasa memperhatikan komunikasi dengan menjalin kegiatan pelayanan yang prima yang dapat merangsang pembelian dan kepuasan pelanggan. Jasa pelayanan yang dilaksanakan perusahaan tersebut dalam upaya untuk memberikan rasa kepuasan, menimbulkan kapercayaan terhadap pihak nasabah, yang merupakan prioritas utama dari penerapan pelayanan yang prima, karena kepuasan pelanggan adalah tingkat perasaan seseoang setelah melihat dan merasakan kinerja hasil yang dia dapatkan.

Usaha yang bergerak di bidang jasa, pelayanan kepada konsumen memegang peranan penting. Kualitas pelayanan harus selalu dijaga dan ditingkatkan untuk meningkatkan kepuasan

Eko dan Bisnis (Riau Economics and Business Reviewe) Volume 11, Nomor 3, 27 September 2020 konsumen. Perbankan yang bergerak di bidang jasa harus bisa memberikan pelayanan yang memuaskan nasabahnya, sehingga nasabah akan meningkatkan loyalitasnya pada perbankan. Peranan manajemen dituntut untuk bisa meningkatkan kualitas pelayanan bagi nasabah. Kualitas pelayanan bisa diwujudkan apabila manajemen perbankan memahami faktor-faktor yang mempengaruhi kualitas pelayanan.

PT Mandiri Tunas Finance memberikan pelayanan kredit kepada nasabah dengan mengharapkan laba yang diperoleh dari bunga kredit tersebut. Persaingan yang ketat di dunia pembiayaan kredit ini membuat PT Mandiri Tunas Finance harus lebih siap dalam memberikan segala fasilitas kredit bagi nasabahnya. Banyak pesaing yang lebih mudah memberikan kredit dan menawarkan tingkat suku bunga kredit yang lebih rendah. Pemberian kredit memuat unsur kepercayaan, pihak pemberi kredit mempercayai pihak penerima kredit akan dapat membayar kreditnya dengan lancar.

PT Mandiri Tunas Finance Cabang pekanbaru harus memberikan kepuasan kepada masyarakat selaku nasabah dan memberikan citra yang baik di mata masyarakat dengan cara memberikan pelayanan yang berkualitas. Melihat keadaan tersebut, PT Mandiri Tunas Finance Cabang Pekanbaru berupaya agar dapat memperbaiki keadaan dengan memberikan pelayanan yang terbaik kepada nasabah. Dengan pelayanan yang baik, diharapkan nasabah akan merasa dihargai dan tidak merasa diabaikan haknya dan akhirnya nasabah sebagai pengguna atau pelanggan dari jasa yang ditawarkan oleh perusahaan PT Mandiri Tunas Finance Cabang Pekanbaru tersebut akan merasa puas.

Pelayanan merupakan unsur yang sangat penting di dalam usaha meningkatkan kepuasan konsumen atau nasabah. Pada dasarnya posisi pelayanan ini merupakan faktor pendukung terhadap aktivitas pemasaran jasa PT Mandiri Tunas

P.ISSN: 1410-7988 E.ISSN: 2614-123X 
Finance Cabang Pekanbaru. Dalam rangka meningkatkan pelayanan penyediaan kredit pada PT Mandiri Tunas Finance Cabang Pekanbaru kepada pelanggan.

Jika pelayanan yang diberikan memenuhi permintaan pelanggan, maka

pelanggan akan merasa puas dan bila jasa pelayanan berada di bawah tingkat yang diharapkan, pelanggan akan merasa kurang/tidak puas. Pelanggan yang merasa tidak puas terhadap kualitas/ pelayanan yang diberikan, dengan sendirinya akan menceritakan kepada orang lain sebagai komplain atas ketidakpuasannya. Oleh karena itu pengukuran kepuasan akan pelayanan yang diberikan oleh PT Mandiri Tunas Finance Cabang Pekanbaru pada nasabah harus selalu dilakukan untuk mengetahui dan merencanakan strategi yang lebih baik di masa mendatang dan lebih meningkatkan kualitas pelayanannya agar dapat memenuhi keinginan dan kebutuhan nasabah serta untuk meminimalisasikan masalah.

Berikut adalah data tentang keluhan yang terjadi pada PT Mandiri Tunas Finance Cabang Pekanbaru yaitu sebagai berikut:

\section{Tabel 1}

\section{Data Jumlah Keluhan PT Mandiri Tunas} Finance Cabang Pekanbaru

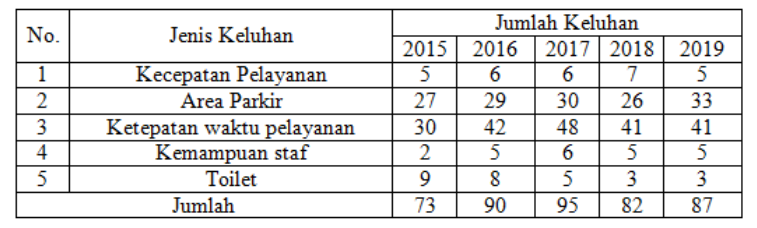

\section{Sumber: PT Mandiri Tunas Finance Cabang Pekanbaru, 2020}

Berdasarkan tabel 1 diatas, bahwa jenis keluhan yang paling sering terjadi pada tahun 2019 adalah keluhan tentang kecepatan pelayanan sebanyak 5 orang menyatakan bahwa kecepatan pelayanan yang diberikan kurang memuaskan. Sedangkan untuk keluhan area parkir sebanyak 33 orang yang menyatakan kurang puas, bahwa area parkir kurang lebar sehingga sulit untuk nasabah yang datang menggunakan mobil. Keluhan untuk ketepatan waktu pelayanan juga sebanyak 41 orang yang menyatakan kurang puas,keluhan untuk kemampuan staf

Eko dan Bisnis (Riau Economics and Business Reviewe) Volume 11, Nomor 3, 27 September 2020 sebanyak 5 orang dan keluhan untuk toilet hanya 3 orang. Sedangkan pada tahun sebelumnya 2018 keluhan yang paling banyak tentang kecepatan pelayanan sebanyak 7 orang, keluhan area parkir 26 orang, ketepatan waktu pelayanan 41 orang, kemampuan staf 5 orang dan3 orang keluhan untuk toilet. Dan pada tahun 2017 keluhan yang paling banyak juga sama seperti tahun 2016 dan 2015 yaitu tentang kecepatan pelayanan. Dari tabel diatas dapat dilihat bahwa masih banyak keluhan pelanggan akibat berbagai hal yang ada di PT Mandiri Tunas Finance Cabang Pekanbaru terbukti bahwa pelayanan pada perusahaan ini masih kurang baik, dengan demikian penulis tertarik untuk meneliti dan mengetahui lebih jauh tentang kualitas pelayanan yang diterapkan perusahaan.

Pelayanan yang baik disertakan dengan fasilititas sarana dan prasarana yang lengkap mampu meningkatkan kepuasan bagi nasabah PT. Mandiri Tunas Finance Cabang Pekanbaru. Jika sarana dan prasarana yang tidak memadai konsumen cenderung menurunkan

\section{TINJAUAN PUSTAKA}

\section{Pengertian Kualitas Pelayanan}

Goeth dan Davis dalam Tjiptono (2012:51) menyatakan bahwa kualitas pelayanan merupakan suatu kondisi dinamis yang berhubungan dengan produk, jasa, manusia, proses dan lingkungan yang memenuhi atau melebihi harapan.

\section{Dimensi Kualitas Pelayanan}

$$
\text { Menurut Kotler (2012:284) }
$$

menyebutkan lima dimensi kualitas pelayanan yang harus dipenuhi yaitu :

1. Bukti Fisik (tangibles) yaitu penampilan fisik layanan perusahaan, seperti penampilan fasilitas fisik, peralatan, personel, kebersihan, kerapian dan media komunikasi.

2. Kehandalan (reliability)yaitu kemampuan perusahaan untuk melaksanakan jasa yang dijanjikan dengan tepat dan terpercaya.

3. Daya tanggap (responsiveness) yaitu daya tanggap perusahaan dalam memberi layanan bagi pelanggan dan

P.ISSN: 1410-7988 E.ISSN: 2614-123X 
memberikan jasa dengan sigap dan cepat dalam melayani menangani transaksi dan penanganan keluhan pelanggan.

4. Jaminan (assurance) yaitu kemampuan perusahaan memberi jaminanpelayanan yang merupakan pengetahuan dan kesopanan karyawan serta kemampuan mereka untuk menimbulkan kepercayaan dan keyakinan.

5. Empati (emphaty) yaitu kesediaan karyawan dan pengusaha untuk lebih peduli memberikan perhatian secara pribadi kepada pelanggan.

\section{Pengertian Kepuasan Nasabah}

Menurut Zeithaml dan Bitner dalam Marwanto (2015:100) mengatakan bahwa kepuasan yang dirasakan oleh seorang pelanggan juga mempengaruhi oleh beberapa faktor seperti: kualitas pelayanan, kualitas produk, harga, faktor situasi, dan tentunya faktor pribadi dari pelanggan.

Menurut Lovelock dalam Marwanto (2015:100) kepuasan pelanggan adalah keadaan emosional, sebuah gambaran reaksi pasca pembelian, dapat berupa kemarahan, kegembiraan, atau kesenangan.Maka tidak heran banyak perusahaan yang sangat terobsesi dengan kepuasan pelanggan.

\section{Indikator Kepuasan Nasabah}

Menurut Kotler dalam Tjiptono (2011:314) mengidentifikasi empat metode untuk mengukur kepuasan pelanggan : system keluhan dan saran, Ghost Shopping, lost costumer analysis, dan survei kepuasan pelanggan.

\section{Pengaruh Kualitas Pelayanan Terhadap Kepuasan Nasabah}

Menurut Rianto Zalukhu, et all dalam Jurnal Manjemen \& Akuntansi (2013:102) sistem pelayanan yang baik perlu mengetahui dimensi kualitas pelayanan yang meliputi: Bukti Fisik (tangibles), Kehandalan (reliability), Daya tanggap (responsiveness), Jaminan (assurance), dan Empati (emphaty). Sehingga dapat disimpulkan bahwa kualitas pelayanan suatu perusahaan merupakan salah satu faktor yang mempengaruhi kepuasaan

Eko dan Bisnis (Riau Economics and Business Reviewe) Volume 11, Nomor 3, 27 September 2020 nasabah dalam membeli suatu produk atau jasa yang ditawarkan atau dijual oleh sutau perusahaan.Kebersihan perusahaan dalam memberikan pelayanan yang lebih kepada nasabah akanmembuat nasabah menjadi loyal dalam menggunakan produk yang ditawarkan secara berulang ulang.Dengan demikian dapat diketahui bahwa kualitas pelayanan mempunyai pengaruh terhadap kepuasan nasabah.

\section{METODE}

\section{Lokasi Penelitian}

Penelitian ini mengambil lokasi yang berada di PT Mandiri Tunas Finance Cabang Pekanbaru yang berlamat di jalan Arifin ahmad komplek bisnis center No. 2526 Pekanbaru.

\section{Jenis dan Sumber Data \\ Data primer}

Menurut (Sugiyono, 2010: 137) yaitu data yang dibuat oleh peneliti untuk maksud khusus menyelesaikan permasalahan yang sedang ditanganinya. Data dikumpulkan sendiri oleh peneliti langsung dari sumber pertama atau tempat objek penelitian dilakukan. Maka data primer penelitian ini adalah data-data PT Mandiri Tunas Finance Cabang Pekanbaru yang saya terimalangsung : struktur organisasi, data karyawan dan nasabah.

\section{Data sekunder}

Menurut (Sugiyono, 2010: 137) yaitu data yang telah dikumpulkan untuk maksud selain menyelesaikan masalah yang sedang dihadapi. Data ini dapat ditemukan dengan cepat. Dalam penelitian ini yang menjadi sumber data sekunder adalah literatur, artikel, jurnal serta situs di internet yang berkenaan dengan penelitian yang dilakukan. Dalam penelitian ini yang menjadi data sekunder adalah, seperti sejarah PT Mandiri Tunas Finance Cabang Pekanbaru, dan data-data yang mendukung lainnya.

\section{Populasi}

Populasi Menurut Sugiyono (2013:115) "Populasi adalah keseluruhan dari objek yang akan diteliti". Adapun yang menjadi

P.ISSN: 1410-7988 E.ISSN: 2614-123X 
populasi penelitian ini adalah seluruh nasabah pada tahun 2019 yang berjumlah 2.390 nasabah.

\section{Sampel}

Sampel Menurut Sugiyono (2013: 116) "Sampel adalah bagian dari jumlah dan karakteristik yang dimiliki oleh populasi tersebut". Besarnya jumlah sampel dalam penelitian ini, maka peneliti menggunakan rumus Slovin untuk memperkecil jumlah populasi, hal tersebut dikarenkan keterbatasan waktu, biaya, dan tenaga peneliti, berikut adalah rumus yang digunakan, yaitu :

Dimana :

$$
\mathrm{n}=\frac{\mathrm{N}}{1+\mathrm{Ne} 2}
$$

$$
\begin{aligned}
& \mathrm{N}=\text { Jumlah populasi } \\
& \mathrm{n}=\text { Sampel sampel } \\
& \mathrm{e}=10 \% \\
& \mathrm{n}=\frac{2390}{1+2390(0.1) 2} \\
& \mathrm{n}=95,9
\end{aligned}
$$

Dengan demikian jumlah sampel adalah dibulatkan menjadi 96 nasabah. Untuk menentukan sampel yang akan digunakan dalam penelitian digunakan metode Sampling Accidental. Teknik Sampling Accidental dilakukan pemilihan anggota sampelnya terhadap orang atau benda yang kebetulan ada atau dijumpai dan dipandang orang yang dijumpai tersebut cocok dijadikan sumber data.

\section{Analisis Data}

Menurut Sugiyono (2014:21) analisis deskriptif adalah analisis yang digunakan untuk menganalisa data dengan cara mendeskripsikan atau menggambarkan data yang telah terkumpul sebagaimana adanya tanpa bermaksud membuat kesimpulan yang berlaku untuk umum atau generalisasi. Metode Penelitian Kuantitatif dapat diartikan sebagai metode penelitian yang digunakan untuk meneliti pada populasi atau sampel tertentu, menggunakan instrument penelitian analisis data bersifat statistik dengan tujuan untuk menguji hipotesis yang telah ditetapkan.
HASIL

\section{Metode Deskriptif}

Analisis secara deskriptif pada variabel Kualitas Pelayanan menunjukkan nilai ratarata yang diperoleh sebesar 3,96. Hal ini menunjukkan Kualitas Pelayanan PT Mandiri Tunas Finance Cabang Pekanbaru sudah baik. Analisis secara deskriptif pada variabel Kepuasan Nasabah menunjukkan nilai rata-rata yang diperoleh sebesar 4,03. Hal ini menunjukkan Kepuasan NasabahPT Mandiri Tunas Finance Cabang Pekanbaru sudah baik.

\section{Metode Kuantitatif}

\section{Uji Regeresi Linier Sederhana}

Analisis yang digunakan umtuk melihat arah hubungan antara variabel bebas terhadap terikat, serta untuk melihat besaran perubahan peningkatan variabel terikat, akibat dari perubahan variabel bebas sebesar satu-satuan. Berikut adalah hasil output regresi linier sederhana.

\section{Tabel 2}

\section{Regresi Linier Sederhana}

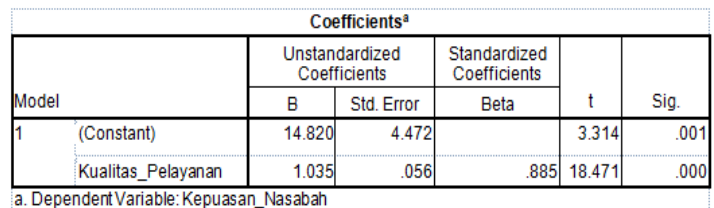

Sumber: Data Olahan, 2020

Dari tabel 2 di atas dapat diperoleh persamaan regresi linear sederhana sebagai berikut: $Y=14,820+1,035 X$. Persamaan ini dapat diartikan sebagai berikut:

1. Konstanta sebesar 14,820 , artinya jika variabel bebas bernilai nol, maka kepuasan nasabah pada PT Mandiri Tunas Finance Cabang Pekanbaru sebesar 14,820.

2. Koefisien regresi variabel Kualitas Pelayanan sebesar 1,035 artinya jika variabel Kualitas Pelayanan bertambah, maka Kepuasan Nasabah pada PT Mandiri Tunas Finance Cabang Pekanbaru sebesar 1,035.

\section{Uji t}

Uji_t adalah uji statistik yang digunakan umtuk menguji hipotesis 
penelitian, yaitu apakah menerima hipotesis atau menolak. Yaitu dengan membandingkan antara nilai t_hitung dengan nilai t_tabel. Menentukan nilai t_tabel adalah dengan rumus: $\mathrm{n}-2$, baris dan pada alfa 0,05/2, kolom, maka diperoleh: 96-2 = 94 (baris) dan alfa 0,05/2 (kolom), maka diperoleh nilai t_tabel yaitu 1,98552. Berdasarkan tabel 5.56 $\mathrm{di}$ atas terlihat bahwa nilai t hitung untuk variabel bebas memiliki nilai > dari nilai t_tabel (1,98552), maka dapat disimpulkan bahwa variabel bebas memiliki pengaruh yang signifikan terhadap variabel terikat. Sedangkan variabel memiliki nilai t_hitung $(18,471)$ lebih besar > dari nilai t_tabel $(1,98552)$, maka dapat disimpulkan bahwa variabel bebas Kualitas Pelayanan berpengaruh signifikan terhadap Kepuasan Nasabah pada PT Mandiri Tunas Finance Cabang Pekanbaru.

\section{Koefisien Determinasi $\left(\mathbf{R}^{2}\right)$}

Koefisien determinasi adalah nilai koefisien yang digunakan untuk melihat seberapa besar pengaruh atau kontribusi variabel bebas terhadap varaibel terikat, yaitu semakin tinggi nilai Koefisien determinasi atau mendekati 1 , maka semakin tinggi atau baik variabel terikat. Berikut adalah hasil Koefisien Determinasi:

Tabel 3

Nilai Koefisien Determinasi

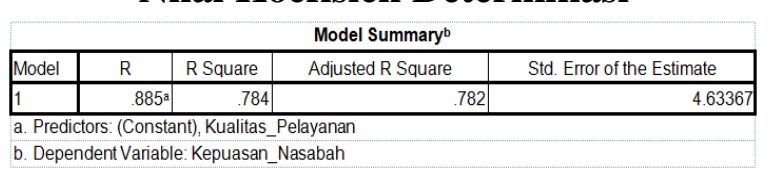

Sumber: Data Olahan, 2020

Berdasarkan tabel 3 di atas diperoleh angka $\mathrm{R}$ Square sebesar 0,784 atau menunjukkan bahwa $78,4 \%$ besarnya pengaruh variabel Kualitas Pelayanan terhadap Kepuasan Nasabah pada PT Mandiri Tunas Finance Cabang Pekanbaru. Sedangkan sisanya sebesar 21,6\% dipengaruhi oleh variabel lain yang tidak dimasukkan dalam penelitian ini atau bahwa variabel terikat mampu dijelaskan oleh variabel bebas, artinya model yang digunakan sudah selesai.

\section{SIMPULAN}

Berdasarkan hasil penelitian, maka Kesimpulan dalam penelitian ini adalah:

a. Berdasarkan hasil regresi sederhana diperoleh persamaan $\mathrm{Y}=14,820+$ 1,035, yaitu memiliki arah hubungan positif antara variabel bebas terhadap variabel terikat.

b. Variabel bebas memiliki pengaruh yang signifikan terhadap variabel terikat. Sedangkan variabel memiliki nilai t_hitung $(18,471)$ lebih besar > dari nilai t_tabel (1,98552), maka dapat disimpulkan bahwa variabel bebas Kualitas Pelayanan berpengaruh signifikan terhadap Kepuasan Nasabah pada PT Mandiri Tunas Finance Cabang Pekanbaru.

Diperoleh angka $\mathrm{R}$ Square sebesar 0,784 atau menunjukkan bahwa 78,4\% besarnya pengaruh variabel Kualitas Pelayanan terhadap Kepuasan Nasabah pada PT Mandiri Tunas Finance Cabang Pekanbaru. Sedangkan sisanya sebesar 21,6\% dipengaruhi oleh variabel lain yang tidak dimasukkan dalam penelitian ini atau bahwa variabel terikat mampu dijelaskan oleh variabel bebas, artinya model yang digunakan sudah selesai.

\section{DAFTAR RUJUKAN}

Andespa, Roni. 2014. Metodologi Riset Bisnis. Al-Huda Press:Pekanbaru.

Aryani, Dwi. 2010. Pengaruh Kualitas Pelayanan Terhadap Kepuasan Pelanggan Membentuk Loyalitas Pelanggan. Universitas Indonesia: Jakarta

Dimas, Reza. 2012. Pengaruh Kualitas Pelayanan Terhadap Kepuasan pelanggan Pengguna Lapangan Futsal (studi kasus pada IFI Futsal Bandung).Universitas Telkom Bandung:Bandung.

Ghozali, Imam. 2013. Aplikasi Analisis Multivariate dengan Program IBM SPSS 21 Update PLS Regresi. 
Semarang: Badan Penerbit

Universitas Diponegoro.

Husein, Umar. 2010. Riset pemasaran dan bisnis. Gramedia Pustaka Utama, Jakarta.

Irawan, H. 2009. 10 Prinsip Kepuasan Pelanggan. Jakarta: Elex Media Komputindo.

Kotler, Philip dkk. 2012. Manajemen Pemasaran Perspektif Asia, Buku Dua, Edisi Pertama. Andy: Yogyakarta.

Mangkunegara, A.A Anwar Prabu. 2012. Manajemen Sumber Daya Manusia. Bandung: PT. Remaja Rosdakarya.

Marwanto, Aris. 2015. Marketing Sukses.Yogyakarta :Kobis.

Riduwan dan Sunarto. 2010. Pengantar Statistika. CV Alfabeta: Bandung.

Siregar, Syofian. 2014. Metode Penelitian Kuantitatif Dilengkapi Dengan Perbandingan Perhitungan Manual Dan SPSS. Kencana: Jakarta.

Sugiyono. 2010. Metode Penelitian Kuantitatif Kualitatif dan $R \& D$. Alfabeta: Bandung. 2011. Metode Penelitian Administratif. Alfabeta: Bandung. 2012. Metode Penelitian Kuantitatif Kualitatif dan $R \& D$. Alfabeta: Bandung.

2013. Metode Penelitian Pendidikan Pendekatan Kuantitatif, Kualitatif, dan $R \& D$. Alfabeta: Bandung. . 2011. Service Management Mewujudkan Layanan Prima. Edisi 2. Andi Offset: Yogyakarta.

Sumardi.2019. Pengaruh Kualitas Pelayanan Terhadap Kepuasan Konsumen pada UD. Asean Motor Bagansiapi-Api. Sekolah Tinggi Ilmu Ekonomi Riau: Pekanbaru.

Tjiptono, Fandy. 2012. Strategi Pemasaran, ed. 3. Yogyakarta: Andi. 